\title{
Research on the Application of Fine Iron Tailings in Surface Mortar for External Thermal Insulation on Outer-walls
}

\author{
HUANG Tianyong 1, 2, 3 a , ZHANG Yinxiang ${ }^{1,2}$, CHEN Xufeng ${ }^{1,2}$, ZHENG \\ Yongchao $^{1,2}$, YAN Peiyu ${ }^{3}$ \\ ${ }^{1}$ State Key Laboratory of Solid Waste Reuse for Building Materials, China \\ ${ }^{2}$ Beijing Engineering and Technology Research Center of Dry-mixed Mortar, China \\ ${ }^{3}$ Tsinghua University, china \\ ahatty555@163.com
}

Keywords: Fine iron tailings, surface mortar, particle shape, gradation

Abstract: Three gradations of fine iron tailings are selected to prepared surface mortar for external thermal insulation on outer-walls for replacing natural sand. The working performance and mechanical performance of the surface mortar for external thermal insulation on outer-walls are studied. The results show that the water requirements of surface mortar for external thermal insulation on outer-walls is almost no difference at same consistency when the dosage of $0-0.1 \mathrm{~mm}, 0.1-0.3 \mathrm{~mm}$ and $0.3-0.5 \mathrm{~mm}$ fine iron tailings is respectively below $80 \mathrm{~g} / \mathrm{kg}, 100 \mathrm{~g} / \mathrm{kg}, 150 \mathrm{~g} / \mathrm{kg}$, and the flexural strength, compressive strength and tensile adhesive strength at $28 \mathrm{~d}$ of surface mortar for external thermal insulation on outer-walls is higher than it prepared natural sand. The water requirements of surface mortar for external thermal insulation on outer-walls prepared by fine iron tailings instead of all natural sand is $24 \%$ higher than it by prepared natural sand, the flexural strength, compressive strength and tensile adhesive strength at $28 \mathrm{~d}$ of surface mortar for external thermal insulation on outer-walls is slightly lower than it prepared by natural sand. The working performance and mechanical performance of the surface mortar for external thermal insulation on outer-walls by fine iron tailings instead of all natural sand can meet requirements of JC/T 2084-2011.

\section{Introduction}

Fine iron tailing are a kind of solid mineral waste after processing and magnetic separation. Fine iron tailing were produced as high as 1.5 tons per year in china ${ }^{[1-2]}$. The large amount of fine iron tailings not only cause serious pollution to the air and water, but also cause safety problems. Many experts and scholars have carried out systematic research on iron tailings for concrete ${ }^{[3-5]}$, and the concrete prepared by iron tailings has been used in the construction engineering. The particle size of fine iron tailings is less than $0.5 \mathrm{~mm}$; it is difficult and low added value that fine iron tailings prepared concrete

${ }^{[6-7]}$. Natural sand is a kind of limited natural resources. With the development of china's infrastructure, the resources of natural sand are more and scarcer. The regulations prohibiting the exploitation of natural sand were promulgation to protect environment. Natural sand is more and more expensive, and the supply cannot meet the demand of engineering construction ${ }^{[8-9]}$.

The natural sand less than $0.5 \mathrm{~mm}$ is selected to prepare surface mortar for external thermal insulation on outer-walls. Its dosage is more than $60 \%$. The fine iron tailings meet particle size requirement of surface mortar for external thermal insulation on outer-walls. So the surface mortar for external thermal insulation on outer-walls is prepared by fine iron tailings instead of natural sand. That not only can solve the environmental problems and safety problems caused by fine iron tailings, but also ease the shortage of natural sand resources. Different particle sizes and different dosages of fine iron tailings are chosen to substitute the natural sand. The working performance and mechanical properties of the surface mortar for external thermal insulation on outer-walls are studied. 


\section{Experimental}

\section{Raw Materials}

The surface mortar for external thermal insulation on outer-walls were prepared from $\mathrm{P} \cdot \mathrm{O} 42.5$, fly ash, natural sand, fine iron tailings, sierozem powder, redispersion emulsoid powder, cellulose ether, water-reducing admixture, $5 \mathrm{~mm}$ fibber and water. Chemical composition and physical-mechanical properties of $\mathrm{P} \cdot \mathrm{O} 42.5$ are presented in Table 1,2. All parameters were determined by standard procedures described in GB 175-2007. The natural sand include 40-70 mesh (equivalent of $0.2 \mathrm{~mm}-0.4 \mathrm{~mm}$ ) and $70-140$ mesh (equivalent of $0.1 \mathrm{~mm}-0.2 \mathrm{~mm}$ ). The fine iron tailings are divided $0 \mathrm{~mm}-0.1 \mathrm{~mm}, 0.1 \mathrm{~mm}-0.3 \mathrm{~mm}$ and $0.3 \mathrm{~mm}-0.5 \mathrm{~mm}$ three gradation. Chemical composition, X-ray diffraction pattern and radioactive detection of two fine iron tailings presented in Table 1, Figure 1 and Table 3. It can be seen from Table 1 and Figure 1, the main chemical composition, proportion and X-ray diffraction pattern of two fine iron tailings are very similar. The mineral composition of fine iron tailings mainly are diopside, magnesiohornblende, dolomite, scolecite. Table 3 shows the $\mathrm{I}_{\text {inside }}$ and $\mathrm{I}_{\text {outside }}$ of fine iron tailings are far below 1.0, radioactivity of two fine iron tailings can satisfy the requirement of GB 6566-2010. So the surface mortar for external thermal insulation on outer-walls prepared from two fine iron tailings don't have bad influence on health.

Tab. 1 Chemical compositions of cement and fine iron tailings $1 \%$

\begin{tabular}{ccccccccc}
\hline chemical compositions & $\mathrm{SiO}_{2}$ & $\mathrm{Al}_{2} \mathrm{O}_{3}$ & $\mathrm{Fe}_{2} \mathrm{O}_{3}$ & $\mathrm{CaO}$ & $\mathrm{MgO}$ & $\mathrm{SO}_{3}$ & $\mathrm{R}_{2} \mathrm{O}$ & Loss \\
\hline cement & 21.10 & 5.45 & 3.87 & 61.23 & 2.01 & 1.96 & 2.43 & 1.95 \\
fine iron tailings-Z & 39.27 & 9.63 & 14.97 & 15.12 & 10.93 & 0.90 & - & - \\
fine iron tailings-F & 39.16 & 9.64 & 15.79 & 13.47 & 11.66 & 1.99 & - & - \\
\hline
\end{tabular}

Tab. 2 Physical properties of cement

\begin{tabular}{cccccccc}
\hline \multirow{2}{*}{$\begin{array}{c}\text { specific } \\
\text { surface } / \mathrm{m}^{2} / \mathrm{kg}\end{array}$} & $\begin{array}{c}\text { Water for standard } \\
\text { consistency/\% }\end{array}$ & \multicolumn{2}{c}{$\begin{array}{c}\text { setting } \\
\text { time/min }\end{array}$} & \multicolumn{2}{c}{$\begin{array}{c}\text { flexural } \\
\text { strength/MPa }\end{array}$} & \multicolumn{2}{c}{$\begin{array}{c}\text { compressive } \\
\text { strength/MPa }\end{array}$} \\
\cline { 3 - 8 } & & initial & final & $3 \mathrm{~d}$ & $28 \mathrm{~d}$ & $3 \mathrm{~d}$ & $28 \mathrm{~d}$ \\
\hline 365 & 29.6 & 75 & 250 & 7.08 & 9.04 & 35.5 & 53.2 \\
\hline \multicolumn{6}{c}{ Tab. 3 Radioactivity of fine iron tailings } \\
\hline species & test weight/g & $\mathrm{Ra}$ & $\mathrm{Th}$ & $\mathrm{K}$ & $\mathrm{I}_{\text {inside }}$ & $\mathrm{I}_{\text {outside }}$ \\
\hline fine iron tailings-Z & 277.27 & 3.27 & 2.13 & 228.85 & 0.016 & 0.072 \\
fine iron tailings-F & 318.04 & 1.67 & 1.6 & 227.05 & 0.008 & 0.065 \\
\hline
\end{tabular}

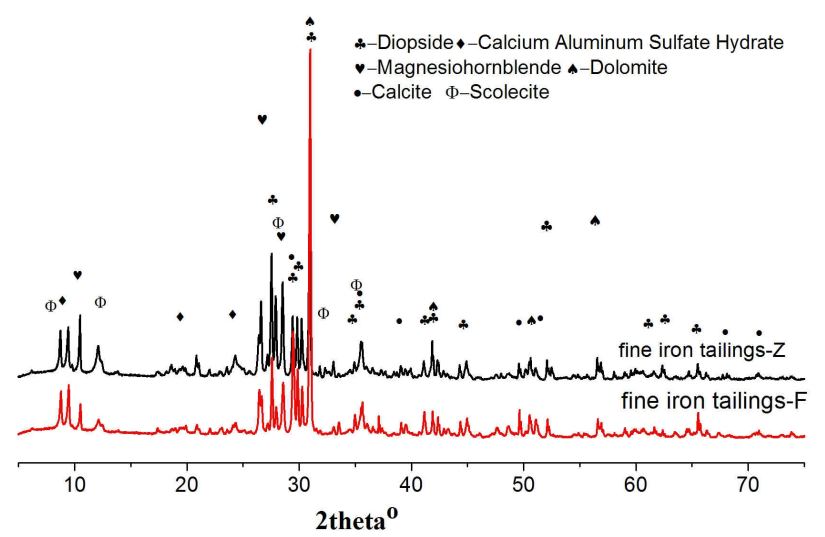

Fig.1 X-ray diffraction pattern of fine iron tailings

\section{Experimental process}

Different gradation of the fine iron tailings- $F$ is only selected to prepared surface mortar for external thermal insulation on outer-walls because fine iron tailings- $F$ is similar to fine iron tailings- $Z$. The proportion of $0-0.1 \mathrm{~mm}$ fine iron tailings-F replaces $70-140$ mesh natural sand is $60 \mathrm{~g} / \mathrm{kg}, 80 \mathrm{~g} / \mathrm{kg}$, $100 \mathrm{~g} / \mathrm{kg}, 120 \mathrm{~g} / \mathrm{kg}$; The proportion of $0.1-0.3 \mathrm{~mm}$ fine iron tailings-F replaces $70-140 \mathrm{mesh}$ natural sand is $50 \mathrm{~g} / \mathrm{kg}, 100 \mathrm{~g} / \mathrm{kg}, 150 \mathrm{~g} / \mathrm{kg}, 200 \mathrm{~g} / \mathrm{kg}, 300 \mathrm{~g} / \mathrm{kg}$; The proportion of $0.3-0.5 \mathrm{~mm}$ fine iron tailings-F replaces $40-70 \mathrm{mesh}$ natural sand is $50 \mathrm{~g} / \mathrm{kg}, 100 \mathrm{~g} / \mathrm{kg}, 150 \mathrm{~g} / \mathrm{kg}, 200 \mathrm{~g} / \mathrm{kg}$. Finally, the $0 \mathrm{~mm}-0.1 \mathrm{~mm}$, 0.1-0.3mm and 0.3-0.5mm fine iron tailings-F replace all 40-70 mesh and 70-140 mesh natural sand, the proportion of $0 \mathrm{~mm}-0.1 \mathrm{~mm}, 0.1-0.3 \mathrm{~mm}$ and $0.3-0.5 \mathrm{~mm}$ fine iron tailings- $\mathrm{F}$ and fine iron tailings- $\mathrm{Z}$ is 
respectively $120 \mathrm{~g} / \mathrm{kg}, 300 \mathrm{~g} / \mathrm{kg}$ and $200 \mathrm{~g} / \mathrm{kg}$. The fine aggregate mix proportions of surface mortar for external thermal insulation on outer-walls are shown in Table 4.

The consistency, bulk density, water-retention rate, application property flexural strength, compressive strength and tensile adhesive strength of surface mortar for external thermal insulation on outer-walls are determined when its consistency is $95 \pm 3 \mathrm{~mm}$ as described in JC/T 2084-2011.

Tab. 4 Fine aggregate mix proportions of surface mortar for external thermal insulation on outer-walls

\begin{tabular}{cccccc}
\hline species & $40-70$ mesh & $70-140$ mesh & $0-0.1 \mathrm{~mm}$ & $0.1-0.3 \mathrm{~mm}$ & $0 .-0.5 \mathrm{~mm}$ \\
\hline $0-0$ & 200 & 420 & - & - & - \\
$1-1$ & 200 & 360 & 60 & - & - \\
$1-2$ & 200 & 340 & 80 & - & - \\
$1-3$ & 200 & 320 & 100 & - & - \\
$1-4$ & 200 & 300 & 120 & - & - \\
$2-1$ & 200 & 370 & - & 50 & - \\
$2-2$ & 200 & 320 & - & 100 & - \\
$2-3$ & 200 & 270 & - & 150 & - \\
$2-4$ & 200 & 220 & - & 200 & - \\
$2-5$ & 200 & 120 & - & 300 & - \\
$3-1$ & 150 & 420 & - & - & 50 \\
$3-2$ & 100 & 420 & - & - & 100 \\
$3-3$ & 50 & 420 & - & - & 150 \\
$3-4$ & - & 420 & - & - & 200 \\
F-1 & - & - & 120 & 300 & 200 \\
Z-2 & - & - & 120 & 300 & \\
\hline
\end{tabular}

\section{Results and Discussion}

\section{Effect of fine iron tailings on working performance of surface mortar for external thermal insulation on outer-walls}

The surface mortar for external thermal insulation on outer-walls is prepared according to Table 4 . The water requirement of surface mortar for external thermal insulation on outer-walls is different because the consistency is controlled in $95 \pm 3 \mathrm{~mm}$. The water requirement, consistency, water-retention, bulk density and application property of surface mortar for external thermal insulation on outer-walls are shown in Table 5.

Tab. 5 Working performance of surface mortar for external thermal insulation on outer-walls

\begin{tabular}{|c|c|c|c|c|c|c|}
\hline \multirow{2}{*}{ species } & \multirow{2}{*}{$\begin{array}{c}\text { water } \\
\text { requirement/g/kg }\end{array}$} & \multicolumn{2}{|c|}{ consistency $/ \mathrm{mm}$} & \multirow{2}{*}{$\begin{array}{c}\text { water-retention } \\
\text { rate } / \%\end{array}$} & \multirow{2}{*}{$\begin{array}{c}\text { bulk } \\
\text { density } / \mathrm{kg} / \mathrm{m}^{3}\end{array}$} & \multirow{2}{*}{ application property } \\
\hline & & $0 \mathrm{~min}$ & $30 \mathrm{~min}$ & & & \\
\hline $0-0$ & 190 & 98 & 87 & 93.5 & 1637 & good \\
\hline $1-1$ & 190 & 87 & 82 & 94.5 & 1618 & good \\
\hline $1-2$ & 190 & 93 & 78 & 94.6 & 1625 & better \\
\hline $1-3$ & 200 & 97 & 85 & 95.1 & 1587 & good \\
\hline $1-4$ & 205 & 94 & 80 & 95.1 & 1602 & good \\
\hline $2-1$ & 190 & 98 & 86 & 94.2 & 1625 & good \\
\hline $2-2$ & 190 & 93 & 79 & 94.5 & 1598 & good \\
\hline $2-3$ & 195 & 92 & 75 & 94.7 & 1635 & better \\
\hline $2-4$ & 210 & 96 & 81 & 94.6 & 1598 & good \\
\hline $2-5$ & 215 & 94 & 78 & 95.0 & 1605 & good \\
\hline $3-1$ & 190 & 97 & 80 & 94.1 & 1592 & good \\
\hline $3-2$ & 190 & 95 & 74 & 94.2 & 1613 & better \\
\hline $3-3$ & 190 & 92 & 75 & 94.5 & 1586 & good \\
\hline $3-4$ & 200 & 93 & 78 & 94.7 & 1665 & good \\
\hline F-1 & 235 & 96 & 82 & 96.2 & 1623 & good \\
\hline $\mathrm{Z}-2$ & 235 & 98 & 86 & 95.8 & 1614 & good \\
\hline
\end{tabular}

It can be seen from Table 5 that when the dosage of $0-0.1 \mathrm{~mm}, 0.1-0.3 \mathrm{~mm}$ and $0.3-0.5 \mathrm{~mm}$ fine iron tailings is respectively below $80 \mathrm{~g} / \mathrm{kg}, 100 \mathrm{~g} / \mathrm{kg}, 150 \mathrm{~g} / \mathrm{kg}$, the water requirements of surface mortar for external thermal insulation on outer-walls is almost no difference at same consistency. When the dosage of $0-0.1 \mathrm{~mm}, 0.1-0.3 \mathrm{~mm}$ and $0.3-0.5 \mathrm{~mm}$ fine iron tailings is respectively above $80 \mathrm{~g} / \mathrm{kg}, 100 \mathrm{~g} / \mathrm{kg}$, 
$150 \mathrm{~g} / \mathrm{kg}$, the water requirements of surface mortar for external thermal insulation on outer-walls are increased with increasing of the fine iron tailing dosages. The water requirements of surface mortar for external thermal insulation on outer-walls prepared by fine iron tailings instead of all natural sand is $24 \%$ higher than it by prepared natural sand. This is mainly because the shape of natural sand is round, its surface is smooth, while the shape of fine iron tailing is sharp and its surface is rough and uneven ${ }^{[10]}$. The specific surface area of fine iron tailings is great, so the water requirement is high. Some fine iron tailings is added in surface mortar for external thermal insulation on outer-wall, the water requirement don't become high because some fine iron tailings make better gradation The water-retention rate of surface mortar for external thermal insulation on outer-walls prepared by fine iron tailings is higher than it prepared by natural sand, This is mainly because the fine powder of fine iron tailing can improve the water-retention rate of surface mortar for external thermal insulation on outer-walls. The application property of surface mortar for external thermal insulation on outer-walls prepared by fine iron tailings is good. Sometimes the application property of surface mortar for external thermal insulation on outer-walls adding some fine iron tailings is better.

\section{Effect of fine iron tailings on mechanical performance of surface mortar for external thermal insulation on outer-walls}

The mechanical performance of surface mortar for external thermal insulation on outer-walls mainly include the flexural strength, compressive strength, tensile adhesive strength with mortar board and expanded polystyrene board (EPS board ) at 28d, tensile adhesive strength with mortar board and EPS board after soaking 2 days and dry 2 hours. The results are shown in Table 6 .

Tab. 6 Mechanical performance of surface mortar for external thermal insulation on outer-walls/MPa

\begin{tabular}{|c|c|c|c|c|c|c|}
\hline \multirow{2}{*}{ species } & \multirow{2}{*}{$\begin{array}{l}\text { flexural } \\
\text { strength }\end{array}$} & \multirow{2}{*}{$\begin{array}{l}\text { compressive } \\
\text { strength }\end{array}$} & \multicolumn{2}{|c|}{ tensile adhesive strength } & \multicolumn{2}{|c|}{$\begin{array}{c}\text { tensile adhesive strength after } \\
\text { soaking }\end{array}$} \\
\hline & & & $\begin{array}{c}\text { mortar } \\
\text { board }\end{array}$ & $\begin{array}{l}\text { EPS } \\
\text { board }\end{array}$ & mortar board & EPS board \\
\hline $0-0$ & 15.7 & 5.9 & 0.569 & 0.096 & 0.563 & 0.062 \\
\hline $1-1$ & 16.1 & 6.2 & 0.596 & 0.106 & 0.603 & 0.065 \\
\hline $1-2$ & 16.5 & 6.7 & 0.604 & 0.105 & 0.608 & 0.068 \\
\hline $1-3$ & 15.4 & 6.5 & 0.586 & 0.102 & 0.578 & 0.059 \\
\hline $1-4$ & 14.8 & 5.8 & 0.564 & 0.084 & 0.546 & 0.058 \\
\hline $2-1$ & 16.0 & 6.3 & 0.575 & 0.098 & 0.564 & 0.063 \\
\hline $2-2$ & 16.3 & 6.4 & 0.586 & 0.098 & 0.572 & 0.067 \\
\hline $2-3$ & 16.9 & 6.9 & 0.613 & 0.115 & 0.605 & 0.076 \\
\hline $2-4$ & 15.6 & 6.3 & 0.563 & 0.101 & 0.552 & 0.054 \\
\hline $2-5$ & 15.0 & 5.8 & 0.532 & 0.089 & 0.521 & 0.051 \\
\hline 3-1 & 16.2 & 6.2 & 0.578 & 0.099 & 0.565 & 0.065 \\
\hline $3-2$ & 16.8 & 6.9 & 0.595 & 0.102 & 0.587 & 0.069 \\
\hline $3-3$ & 15.6 & 6.3 & 0.608 & 0.106 & 0.601 & 0.070 \\
\hline $3-4$ & 15.4 & 6.4 & 0.559 & 0.096 & 0.552 & 0.057 \\
\hline F-1 & 14.6 & 6.2 & 0.543 & 0.105 & 0.556 & 0.054 \\
\hline Z-2 & 13.0 & 6.0 & 0.527 & 0.094 & 0.538 & 0.058 \\
\hline
\end{tabular}

It can be seen from Table 6 that When the dosage of $0-0.1 \mathrm{~mm}, 0.1-0.3 \mathrm{~mm}$ and $0.3-0.5 \mathrm{~mm}$ fine iron tailings is respectively below $80 \mathrm{~g} / \mathrm{kg}, 100 \mathrm{~g} / \mathrm{kg}, 150 \mathrm{~g} / \mathrm{kg}$, the flexural strength, compressive strength and tensile adhesive strength at $28 \mathrm{~d}$ of surface mortar for external thermal insulation on outer-walls is higher than it prepared natural sand. This is mainly because sharp shape and rough surface of fine iron tailings improve friction among fine aggregate. When the dosage of $0-0.1 \mathrm{~mm}$, $0.1-0.3 \mathrm{~mm}$ and $0.3-0.5 \mathrm{~mm}$ fine iron tailings is respectively above $80 \mathrm{~g} / \mathrm{kg}, 100 \mathrm{~g} / \mathrm{kg}, 150 \mathrm{~g} / \mathrm{kg}$, the flexural strength, compressive strength, tensile adhesive strength with mortar board and expanded polystyrene board (EPS board ) at 28d of surface mortar for external thermal insulation on outer-walls are decreased with increasing of the fine iron tailing dosages. This is mainly because water requirement is increased resulting in greater water-binder ratio, so the flexural strength, compressive strength, tensile adhesive strength with mortar board and expanded polystyrene board (EPS board) at 28d of surface mortar for external thermal insulation on outer-walls are decreased. the flexural strength, compressive strength and tensile adhesive strength at $28 \mathrm{~d}$ of surface mortar for external thermal 
insulation on outer-walls prepared by fine iron tailings instead of all natural sand is slightly lower than it prepared by natural sand, but the mechanical performance of surface mortar for external thermal insulation on outer-walls prepared by fine iron tailings still meet requirements of JC/T 2084-2011.

\section{Conclusions}

(1) The application property of surface mortar for external thermal insulation on outer-walls prepared by fine iron tailings is good. The water-retention rate of surface mortar for external thermal insulation on outer-walls prepared by fine iron tailings is higher than it prepared by natural sand.

(2) When the dosage of $0-0.1 \mathrm{~mm}, 0.1-0.3 \mathrm{~mm}$ and $0.3-0.5 \mathrm{~mm}$ is respectively below $80 \mathrm{~g} / \mathrm{kg}, 100 \mathrm{~g} / \mathrm{kg}$, $150 \mathrm{~g} / \mathrm{kg}$, the water requirements of surface mortar for external thermal insulation on outer-walls is almost no difference at same consistency, the flexural strength, compressive strength and tensile adhesive strength at $28 \mathrm{~d}$ of surface mortar for external thermal insulation on outer-walls is higher than it prepared natural sand.

(3) The water requirements of surface mortar for external thermal insulation on outer-walls prepared by fine iron tailings instead of all natural sand is $24 \%$ higher than it by prepared natural sand, the flexural strength, compressive strength and tensile adhesive strength at $28 \mathrm{~d}$ of surface mortar for external thermal insulation on outer-walls is slightly lower than it prepared by natural sand, but the mechanical performance of surface mortar for external thermal insulation on outer-walls prepared by fine iron tailings still meet requirements of JC/T 2084-2011.

\section{Acknowledgements}

This work was financially supported by the Beijing Science and Technology Program Project Funds (Z151100004915008), Postdoctoral Work Funded Projects of Beijing (2015-ZZ-123).

\section{References}

[1] Bai Run-shan, Yan Peng-liang and Zhang Hui-fang. Present status of applied studies on iron tailings in concrete. Journal of heibei institute of architecture and civil engineering. 2015, 33(4):1-4.

[2] Li Yu-feng, Bao Jing-jing, Zhang Jun-rui. Status analysis of iron tailings comprehensive utilization. China mining magazine. 2015,24(11):77-80,121.

[3] Li De-zhong, NiWen, Zheng Yong-chao. Experimental research on high-strength concrete preparation with large content of iron tailings. Metal mine. 2010(2):167-170.

[4] Cai Ji-wei, Zhang Shao-bo, Hou Gui-xiang. Effects of ferrous mill tailings aggregates on workability and strength of concrete. Journal of wuhan university of technology. 2009, 31(7):104-107.

[5] Chen Dong-ping, Liu Fang, Qi Yan-tao. Research progress in development of utilization of iron tailing in cementitious materials. Environmental engineering. 2015(8):83-86.

[6] Wang Yong-sheng, Wang Li-jun. Application study fine iron tailings used in ready-mix concrete. Ready-mixed concrete. 2011(4):39-41.

[7] Liang Ya-jun, Yang Jian-you. Application study on super tail mineral sand used in ready-mixed concrete. Fujian architecture and construction. 2009(12):26-27.

[8] Zhou Wen-juan, Lin Song. Experimental Study of fine tailing sand mortar. Concrete. 2013(7):108-109,123.

[9] Jia Xin. Performance of iron mine tailing sand and its usage in concrete. Beijing University of Civil Engineering and Architecture. 2013.7. 
[10] Chai Hong-jun, Song Yu-zeng, Wang Xing-yuan. Characteristic of iron tail and the affects on concrete mixing content. Construction Quality. 2010, 28(2):71-75. 